\title{
HIBAH IN THE ADMINISTRATION OF ISLAMIC PROPERTY: IJTIHADI ELEMENTS AND REALITY IN MALAYSIA
}

\author{
${ }^{1}$ Alias Azhar \& Mohd Zakhiri Md.Nor \\ School of Law, College of Law, Government and \\ International Studies, Universiti Utara Malaysia \\ ${ }^{1}$ Corresponding author: az.alias@uum.edu.my
}

Received: 17/5/2019 Revised: 24/9/2019 Accepted: 3/10/2019 Published: 31/7/2019

\begin{abstract}
A guarantee of successful life in this world and the hereafter would be achieved if Muslims live according to Islamic principles and teachings. Property and power that are entrusted to men by Allah SWT ought to be judiciously administered based on Islamic precepts. In brief, the administration of Islamic property aims to achieve hasanah (goodness) not only here but also the hereafter. Islam, as a complete way of life, has outlined the absolute guidance on property administration through a systematic law, i.e. the Islamic law of inheritance by means of wasiat (will), hibah (gift inter vivos) and waqf (charity). This article focused on the instrument of hibah under the administration of Islamic property and this includes comparisons of its principles and the reality of its application in Malaysia. Hibah is an element of the distribution of assets as drawn under the Islamic concept of managing property. Its concept, application and implementation need to be intensely understood. It has been occasionally observed that disputes would take place after the demise of the donor (the person who had exercised hibah) which complicates the distribution of the assets. Therefore, if this instrument is exercised differ entry between institutions but effectively and cautiously in line with the Islamic rules and principles, the rights of those entitled would be certainly safeguarded.
\end{abstract}

Keywords: Hibah, Property administration, Islamic inheritance law, Ijtihad. 


\section{INTRODUCTION}

Islam provides a complete guide to property administration after demise through a comprehensive and systematic Islamic inheritance law (Quran,4:11, 12 and 176). The concept of Islamic property administration and management covers five major elements.

1. Property revenue with effort and energy (Quran, 62:10, Quran, 28:77).

2. Property accumulation through means of savings and investment (Quran, 12:47-48).

3. Property protection for the sake of future comfort (Quran, 59:18).

4. Property distribution through a will of instrument (Quran, 2:180), such as hibah (Quran, 2:177), waqf (Quran, 3:92) and others.

5. Property purification through zakat and charity (Quran, 2:195).

The Muslim society nowadays is keen to use an alternative way of distributing property, i.e through the hibah instrument. Granting of property through hibah is a promoted practice in Islam: inasmuch as it is regarded as the act of al-Birr wa al-Taqwa (virtue, righteousness and piety) (Quran, 5:2). However, some issues arise in Malaysia in administrating hibah due to several factors-Amongst the factors are; firstly; there is no specific law relating to hibah (Wan Harun, 2006). Therefore, there are documentary terms called 'hibah declaration' and 'Hibah trust'. Secondly, the poor understanding of the hibah instrument in depth (Muda, 2008; Abdul Rashid, and Ahmad, 2013) which results in the granting of hibah without the transfer of property or change of name in the property. Consequently, after the demise of the grantor, his heir(s) will begin to dispute the hibah.

Thirdly, a relatively complex hibah verification procedure, which involves a dual legal and administrative system of shariah and civil (Mohd Ridzuan Awang, 2008), is another identified factor. Furthermore, another factor that contributes to the issues is the hibah application ijtihadi-like among fuqaha mazhab (Muhammad alZuhayli, 2001, Muhammad Abu Zahrah, 1978 and al-Sayyid Sabiq, t. t). For example, a group of people make conditional hibah like 
'Umra' and 'Ruqba'2 while in the Syafi'i sect and the in opinion of the fuqaha, the hibah is valid but the terms are not applicable. However, some people may adhere to the opinion of Imam Malik and the Maliki sect that 'Umra' and its conditions are necessary. Mazhab al-Zuhri and Imam Malik also think that 'Ruqba' is legitimate as a will but not as hibah (Abdul Rahman et al., 2016). Yet another issue is Qabd (transfer), which is also part of the elements of ijtihadi in the hibah process and procedures. As a matter of fact, there exists a dominant element of ijtihadi in the implementation of Islamic property administration in Malaysia.

\section{CONCEPT OF HIBAH}

All necessary arrangements are to be made to divide and distribute the property owned by the property owner to the heirs or potential beneficiaries, when the property owner dies. The planning of this distribution shall take place when the owners are still alive (Mohd Fitri, 2007).

Wills are part of the method of distribution of property in Islam. A will' means a charitable act with the right to be exercised after demise. (Ahmad Hidayat, 2002). In short, a will is the transfer of only me third of the property's value or benefit to the non-beneficiary value and the transfer of the property is only after the demise of the owner. Non-beneficiary refers to any individual or organization such as adopted children, grandchildren or orphanages and welfare bodies.

The obvious difference between a will and a hibah is, hibah is a gift from the giver (donor) to a recipient (donee) made on the basis of affection (Ibn Rush, 2003). In principle, property owners can give their property as hibah to anyone they want. Hibah may be

Granted on the demise of either party of the donor or recipient as a condition of ownership to one of the surviving parties. The Hibah donor places a condition where property ownership is only effective if he dies first. The other way around and hibah will return to the donors.

2 Temporary Hibah on the condition that one of the parties is alive. Upon the demise of the donor, the property must be returned to the donor's beneficiary. If the recipient dies, then the property is returned to the donor. 
granted to heirs or non-beneficiaries. The transfer will take effect immediately during the grant or during lifetime. Further debates will be explained later.

Alms is a gift in the form of charity to be given to the needy in the hope of alleviating hardship and facilitating the affairs of the receiver, in order for the giver to get a reward from Allah SWT in the hereafter (Quran, 2:264, Quran, 4:114). The use of alms in the Qur'an is also refered to as Zakat (Quran, 9:60). It is contrary to gift because gifts are rewards or for the glorification of a person. The Hadith of Prophet Muhammad (saw) says: "You give each other gifts, you love each other" (al-Bukhari, t.t, al-Baihaqi, t.t and al'Asqalani, 1979). Gift giving can foster a sense of affection.

Hibah means gifts either in the form of ain (tangible) or otherwise, be it gifts or charities. These three terms have the same meaning. The difference is from the aspect of the purpose of giving, where alms is a gift that is intended to get the reward in the hereafter and it is usually from the rich to the poor, while a gift is to glorify a person and usually it is related to something. In short, every alm and gift are hibah, but not all hibah are alms and gifts.

Hibah according to shariah is an agreement which contains the granting of a person's possession voluntarily to another person during the time of his life without any consideration ( 'iwad) ${ }^{3}$. More specifically ${ }^{4}$, hibah is a grant of property from one party to another without repayment (' $\mathrm{iwad}$ ) during life, voluntarily, not expecting a reward in the hereafter or glorifying someone, using the ijab and qabul or the like (al-Nawawi, 1985 and al-Ramli,1967).

Simply put, to distinguish between general and specific hibah is to refer to the existence of the contract ( $a k a d$ ) or otherwise. General hibah does not need the elements of akad, while special hibah needs to have the element of the akad. Explanation of the hibah category is contained in the judgment of Harun Muda \& Ors. v. Mamat Mandak $\&$ Ors [1999] 3 LNS 2. The case was decided by Ismail bin Yahya,

3 Hibah, in general, includes voluntary gifts, charity and ibra' (debt relief by creditors) that are in force during the donor's life.

4 Hibah, specifically category means the granting of possessions by a person to another without any consideration subject to certain pillars or rules. 
Judge of the Syariah High Court of Terengganu who mentioned the difference between hibah, gifts and alms.

Hibah is encouraged in Islam (Quran, 4:4 and Quran, 2:177) and according to the hadith of the Prophet PBUH, it cannot be withdrawn or cancelled after al-Qabd (al-Nawawi, 2003 and Abi al-Tayyib, 1979). The exception to withdraw hibah is limited to the hibah from a father to his children or from a grandfather to his grandchildren. Receiving hibah is recommended (sunat) provided that the gift is not something illegal and is halal (al-Haydar, t.t).

Literally, hibah can be concluded with the following specific characteristics:

1. A contract of grant of property to a party.

2. Property is ain property (tangible), not a debt or merely a benefit.

3. Hibah is made without any consideration (' $i w a d$ ).

4. Hibah takes effect when the donor is still alive.

5. Made voluntarily without compulsion or influence.

6. A hibah is not intended to reward or glorify a person, which is different from alms and gifts.

7. Hibah is not completed and enforceable before possession by the receipient.

Properties in hibah management shall be in the form of real estate (e.g. house, land, condominium, apartment, etc), company shares (private limited company or public limited company), unit trusts, insurance policies or Takaful and other valuable assets which can be owned and transferred. The purpose and effect of hibah is to simply fulfil the requirements of the donor to whom he wishes to give his property, for example a mother who wants to give her home to her adopted child after her demise. She may declare it through the hibah document. Consequently, the particular house will automatically be left out of the will and will not be given to the heirs. Anyone can make a hibah arrangement on his property to anyone he wants.

\section{HIBAH IN MALAYSIA}

In Malaysia, there is no allocated provision on the hibah being enacted. To date, we apply only the provisions of the jurisdiction of 
the Shariah Court as set out in Item 1, List II, the Ninth Schedule of the Federal Constitution. The provision states the term "gift". The provision indicates that hibah is a part of the affairs placed under the Islamic religious administration of each state and directly involves the jurisdiction of the Shariah Court.

Referring to the provisions contained in the Islamic Religious Laws of the states, there are three different terms are used in reference to hibah. The terms 'alang' during marad al-maut (death-illness) or during life and 'non-reciprocal settlement' are applied in Selangor, Melaka, Pulau Pinang, Johor, Perak, Kedah, Terengganu, Sabah and Sarawak: Negeri Sembilan uses hibah, Pahang and Perlis use the term 'gift', and Kelantan uses 'alang hayat' (Wan Abdul Halim Wan Harun, 2006).

Generally, the provision of hibah exists in the legal system in Malaysia. Hibah involves two major aspects during life and marad al-maut. Most of the Hibah cases litigated in Shariah Courts, involve hibah confirmation (Mohamed Said et al., 2018, Mohd Nor et al., 2018), Hibah disputes value or level such as in the case of Harun Muda \& Ors. v. Mamat Mandak \& Ors [1999] 3 LNS 2 and in the case of Salmiah binti Che Mat v. Zakaria bin Hashim (Journal of Hukum, 2001), and also in the hibah withdrawal case such as in Eshah binti Abdullah and Five Others v. Che Aminah binti Abdul Razak and Two Others [2004] 18 JH (1) 47. With regards to the hibah withdrawal, the case of Mohd Mokhtar bin Haji Abdullah v Fadhilah binti Haji Abdullah \& others [2006] 1 CLJ (Sya) 212 is equally important to be referred, where in this case the appellant appealed against the decision of the Shariah High Court judge who rejected the appellant's claim confirming the withdrawal of his mother's grant with allegations that the hibah was not valid because al-Qabd did not exist. The case of al-Qabd was also discussed in the case of Siti Aishah@ Kalsom binti Dahlan (Muhammad Fathullah Al Haq bin Muhamad Asni et al., 2016). These cases prove that hibah can be challenged in the Shariah Court if disputes occur from legal aspects according to the law of syara' or any of the heirs who disagree with the contents of the hibah after the demise of the donor. Accordingly, application of hibah is becoming more systematic and commercialised today. There are trustee companies that are actively involved in the issue of hibah. Alternative hibah is done to avoid the crisis and the dispute following the demise of the hibah donor. 
Hibah Trust is one of the hibah methods that is characterized by the integration of hibah and trust. The assigned property entrusted by the donor to the trustee will be handed over to the donee after the demise of the donor. In addition, to preserve the rights of the donor from the risk of being expelled from the property by the donee, a separate contract is made to enable the donor to use and manage the property until he dies. In principle, it is equivalent to the Umra' and Ruqba' as discussed earlier.

However, the $56^{\text {th }}$ Islamic Legal Consultative Committee of the Federal Territory on 5 October 2000 ruled that the placement of conditions is permitted after the ijab and qabul. Similarly, the Shariah Advisory Council (SAC) of the Securities Commission Malaysia (SC) also ruled in the 44th meeting on 15 January 2003 that the principle of Hibah Ruqba' can be applied as a Shariah basis. Hibah Ruqba' are used in the hibah's claim form for transactions involving mutual trust with unit trust funds especially for Muslims.

\section{HIBAH DOCUMENTATION}

In fact, the real application of hibah in Malaysia involves the hibah document. Hibah documentation is a special procedure that is encouraged to donors during their lifetime. The function of this document is to ensure the property given to the loved ones (i.e. donee) is accepted without being challenged by other heirs.

In current practice, generally $i j a b$ and qabul are executed in writing and signed by both parties (donors and donee) the presence of two witnesses. This situation differs from the past as hibah created based on verbal confirmation which posed a difficulty in the proving process when there was a claim or denial of the hibah in court (Mohd Ridzuan Awang, 2003).

The benefits of hibah documents are generally to facilitate the process of distributing the property of the deceased (donor) and prevent disputes between the donee and the deceased's heirs over the property's ownership after his demise. Other benefits are:

1. A heir cannot challenge the property that has been arranged for hibah. 
2. Hibah documents are made during the donor's lifetime but the change of title is made after the demise of the donor.

3. Property can be indisputably awarded to non-beneficiaries.

4. Hibah assets are discharged from the will.

5. Property inheritance is clearer.

6. The transfer of ownership process is clearer.

Hibah is effective especially for Muslims who intend to give certain property according to their own formula. However, every contract in Islam has its own rules and requirements to be fulfilled, including the hibah instrument in the aspect of Islamic property administration. 'Aqad (contract) for hibah becomes valid after the rules and the requirements have been fulfilled according to the syara'.

The Rukun (rules) of hibah are; (a) donor of hibah (al-wahib), (b) donee of Hibah (al-mauhub lahu), (c) the things gifted (al-mauhub), and (d) the offer and acceptance or ijab and qabul (sighah). All rules are subject to certain conditions to validate the entire hibah contract (al-Kasani, 2003 and Ibn Rush, 2003).

The legal requirement for the hibah is that the donor must be a legal owner of the property (al-mauhub) and there is no barrier to his ownership and management. Al-wahib is also of sound, mind, has reached puberty and rushd (wise in managing property) (Badran al'Ainain, 1985). Hibah must be done willingly, without influence and free from coercion, otherwise, the hibah will be cancelled (Bisyuni 'Ali, 1997).

Equally important, the legal requirement of the donee is anybody, whether muslim or non-muslim, as long as it does not violate the syara' terms, one who is a mukallaf and is capable of owning and managing the hibah property. If the donee is still a minor or has a disability, hibah may be granted to his representative (wali mal) or trustee on his behalf. The donee is also required to be present during the hibah process (Hisham Qublan, 1985).

The goods or property provided must meet the following requirements (Mustofa al-Khin, et.al., 2003):

1. Halal goods or property.

2. Has value in syara'. 
3. Full ownership of donor.

4. Is transferrable.

5. Absolutely exists during the aqad.

6. Property exists separately and can be separated from the property not included in hibah. Collateral goods may be granted prior to obtaining consent from the chargor or the borrower.

Sighah hibah is a pronounce ment or deed that carries the meaning of the grant and receipt of hibah. It is subject to the following conditions (Muhammad Ramiz, 2003):

1. There is a connection and similarity between ijab and qabul.

2. No specific condition.

3. Not required for a certain period of time. In the case of Hibah Umra' and Ruqba' it is lawful but the terms of the period stipulated are void and inapplicable.

Regarding sighah there is also a concept of acceptance termed alQabd. al-Qabd means getting something, mastering and practising tasarruf (management) of goods or property (al-Kasani, 2003). There is a disagreement about the terms of the acceptance of hibah. The difference in views can be summarized as follows. First The Hanbali and Maliki sects do not require acceptance only by the akad (al-Wahhab, 1998 and Ibn Rush, 2003). It means that although the demise of the donor occurs without the process of submission, the hibah is still valid. Second, Imam Abu Hanifah and Imam Syafi'i assert that acceptance is a legal requirement of hibah (al-Nawawi, t.t, al-Khatib, t.t and al-Kasani, 2003). Thus, if the demise of the donor occurs before the surrender, then the hibah is cancelled. Even in the Syafi'i sect, al-Qabd is a requirement of Luzum (obligatory) (Bahuti,1982). It means the hibah contract is imperfect and cannot be enforced with consent and qabul except after al-Qabd.

Al-Qabd is realized by the type of property, whether movable or immovable (Noor Lizza et.al, 2010, Majallat Majma 'al-Fiqh al-Islami, 1990). For immovable property, al-Qabd can happen by clearing the property, mastering it and doing tasarruf such as delivering the house key. While for movable property, al-Qabd can be done by way of transfer or setting aside the property from perty that is not included in the hibah. 


\section{LEGAL ISSUES RELATED TO HIBAH}

The first issue: When the hibah rukun and requirements are fulfilled, and transferred and received (al-Qabd), then the property is owned by the hibah recipient (the donee). However, an important issue has been identified with regards to the aspect of withdrawal or cancellation of hibah. Generally, the requirement of the cancellation of hibah can be done in three instances: (a) granting of father to child / grandfather to grandchild, (b) existence of resignation mutually between the donor and the donee; or (c) by the judge's decision (Nasrul Hisyam, 2017). However, if the property has been transferred from the hibah recipient (donee) to a third party through sales, wakaf or hibah, then the hibah cannot be withdrawn under any circumstances.

Second issue: Another question, regarding the allowable rate or limit of hibah. In principle there is no limit or a certain rate in the hibah contract. Since the hibah property is the property of the donor, there is no barrier to the owner to grant part or all of his property (Mohamad Ridzuan, 2003). Yet other considerations are also wellthought-out such as fairness if the hibah is given among the children of the property owners. Hibah will be sunat if it is done equally between his children to guarantee justice and makruh if it prefers one child over the others. In addition, hibah will be harus if the father does not have the intention to cause defamation or danger among his children. In fact, the gift of tafdil (preferably) one party over another is only allowed if it does not harm.

Third issue: The issue of granting hibah when the sickness that can cause demise (marad al-maut) also has a wide variety of polemic views. Prior to that, the conditions of marad al-maut need to be identified first. The conditions are (Ahmad Farraj Husayn, 1986):

1. A disease that can actually cause demise.

2. Illnesses that cause death anxiety in the patient's mind.

3. Symptoms indicating that the disease is chronic and critical.

In addition to the above conditions, the special requirements of marad al-maut are as follows (Majallah Majma 'al-Fiqh al-Islami, 1990): 
1. Its duration is within a year. However, if it is over a years then it does not fall into that category.

2. The most common diseases that cause death such as cancer, AIDS $^{5}$ and H1N16.

3. The illness that makes his patient ignore the world again.

The fourth issue: Hibah when marad al-maut is a gift made in a state of illness that can lead to death. The effect of the hibah at the time has a different implementation depending on the donor's condition after giving, whether it will be a hibah or a will. If the donor dies after the pronouncement, property is categorized as will and is subject to the will of law (Mohd Zamro, 2004). In other words, it should not exceed $1 / 3$ of the property of the deceased and does not involve the granting to heirs unless there is agreement from the heirs. But if the giver is still alive after the grant, then it will be hibah.

\section{ADMINISTRATI ON OF HIBAH BY COMMERCIAL INSTITUTIONS IN MALAYSIA}

Generally, there are many companies in Malaysia who carry out commercial-oriented services on will management services and hibah in particular. In view of that, the companies involved also enter into business as franchises registered with the Ministry of Domestic Trade and Consumer Affairs under the Franchise Act 1998. This means that the company is fully monitored and controlled by the Government. The services offered in hibah, in particular, are the hibah documents. Syarikat Amanah Hibah Sdn. Bhd. is listed in the category of companies that are actively involved in the management and planning of hibah (amanah-hibah-sdn-bhd). There is also a company that offers direct home service, a company bearing www. wasiat4U.com.

AIDS stands for "Acquired Immunodeficiency Syndrome". It is a collection of symptoms, and signs. Infection and cancers resulting from the damage to the immune system caused by the HIV. AIDS is the final stage and the most severe form of HIV infection.

6 A virus that is a subtype (H1N1) of the orthomyxovirus (species Influenza A virus of the genus Influenza virus A) causing influenza A, that infects birds, pigs, and humans, and that includes strains which may occur in seasonal epidemics or sometimes pandemics. 
The companies that promote hibah services under Amanah Raya Berhad as are follows: My Legacy Wills Services, KL; Amalan Harmoni Sdn. Bhd., Johor Bahru; Moreclass (M) Sdn. Bhd., Selangor; Perfect Will Services, Selangor; UAS Bistari Management Sdn. Bhd., Johor; Nakiwa Sdn. Bhd., KL; Warisan Mukmin Sdn. Bhd., Selangor; Capaian Aspirasi Sdn. Bhd., Johor; Inkuas Smart Synergy Sdn. Bhd., Negeri Sembilan and Syihab Excellence Agency Sdn. Bhd., Selangor. In addition, there is a company that features an entrepreneurial organization, namely Wasiyyah Shoppe, Kuala Lumpur.

Here the comparisons between the characteristics of the hibah product offered by Amanah Raya Berhad (ARB) (www.amanahraya) and Wasiyyah Shoppe (WS) (www.wasiyyahshoppe.com.my).

\begin{tabular}{|c|c|c|}
\hline $\begin{array}{l}\text { Co. } \\
\text { No. }\end{array}$ & Amanah Raya Berhad (ARB) & Wasiyyah Shoppe (WS) \\
\hline 1. & $\begin{array}{l}\text { A donor may withdraw or cancel } \\
\text { the hibah if made by parents / } \\
\text { grandparents to a child / grandchild }\end{array}$ & $\begin{array}{l}\text { The donor may cancel the hibah granted } \\
\text { to children / grandchildren (only) at any } \\
\text { time. However, hibah to heirs or non- } \\
\text { beneficiaries, who do not fall into the } \\
\text { category of children or grandchildren, } \\
\text { cannot be withdrawn. }\end{array}$ \\
\hline 2. & $\begin{array}{l}\text { Recommended (sunat) if hibah is } \\
\text { equally distributed among the sons } \\
\text { and the daughters, as well as among } \\
\text { the other parents and other relatives. }\end{array}$ & Free distribution formula of hibah. \\
\hline 3. & $\begin{array}{l}\text { Donor can still enjoy hibah property } \\
\text { benefits provided there is consent } \\
\text { after sighah (Hibah Umra'). }\end{array}$ & $\begin{array}{l}\text { Independent recipients (dones), heirs } \\
\text { or non-heirs, Muslims or non-Muslims } \\
\text { including new brothers may share } \\
\text { property with non-Muslim family } \\
\text { members. }\end{array}$ \\
\hline 4. & $\begin{array}{l}\text { If the donee of the hibah dies first, } \\
\text { the hibah property will be in the } \\
\text { donee's will. }\end{array}$ & $\begin{array}{l}\text { If the donee of the hibah dies first, the } \\
\text { hibah property will be returned to the } \\
\text { donor. (Hibah Ruqba'). }\end{array}$ \\
\hline 5. & $\begin{array}{l}\text { Two forms of hibah: } \\
\text { i) Regular hibah. } \\
\text { (Donor-transfer-hibah-donee). } \\
\text { ii) Hibah Trust. } \\
\text { (Donor - Trust Bond Letter - } \\
\text { Trustee). }\end{array}$ & $\begin{array}{l}\text { Hibah documents are made while donor } \\
\text { is alive but property transfer is after } \\
\text { donor's demise. }\end{array}$ \\
\hline 6. & $\begin{array}{l}\text { All kinds of property can be granted } \\
\text { as hibah. }\end{array}$ & $\begin{array}{l}\text { The property in the loan can also be } \\
\text { granted as hibah. }\end{array}$ \\
\hline
\end{tabular}


It turns out there are some distinctive features of the product being offered. First, the difference in feature 2, in which ARB practices Jumhur Fuqaha's views on the problem of flatulent property rates between the hibah donees among the children or family members. The second difference is Hibah Umra' and the Ruqba' application in the 3rd and 4th features. ARB practices Hibah Umra' while WS is Hibah Ruqba'. In addition, WS did not specify the hukm of hibah, even according to its own grant formula. Characteristics of the hibah in Type 5 offers similar possibilities, namely hibah and hibah trust, but it is hard to identify the usual hibah product promotions at Wasiyyah Shoppe except the hibah Trust through a form available online.

In depth comparison of the Hibah declaration form available online shows that, the differences are in terms of the format, content and validity of the form. The form provided by Wasiyyah Shoppe company is a combination of hibah, trust and will. The hibah property is also included in the form which states the withdrawal of hibah and the exception is made if it involves the hibah between the father and the child and the grandfather and grandchildren. There is a clause on the Hibah property stating that,

\section{"If a hibah recipient dies earlier than the donor, the property is returned to the donor".}

This clause is clearly equivalent to the Hibah Ruqba' which is principally valid on hibah but its terms are invalid. But the reality of hibah execution in Malaysia is to allow Hibah Ruqba' in its implementation. Here, it is clear that the trustee is the company that runs the service.

Referring to the second form, it is more like a contract or a private deal and has characteristics of a legal agreement, complete with witnesses and clauses of agreement to comply with the rules and conditions of hibah. There is also a term that states that donors are not allowed to withdraw hibah without expressing an exception to their father's / grandfather's status regarding their children / grandchildren.

The above discussion explains the importance of hibah as an instrument of administration of Islamic property. There are many 
hukm of ijtihadi involving hibah but on the basis of benefits and convenience, they need to be applied best in the framework of fundamental Shariah principles.

\section{CONCLUSION}

Implementation of hibah in Malaysia is well accepted and is growing rapidly. This is supported by the existence of commercial companies that offer hibah's writing, preparation and problem solving services in almost all states. After understanding the true concept and principles of hibah, we should implement the hibah management very seriously. However, in terms of hukm that is ijtihadi and if there is a khilafiah (different views of Islamic scholars), we must deal with it systematically and consistently. Technical and legal aspects should be streamlined and standardized so that the confusion can be avoided. The documentation aspect is of paramount importance in avoiding the dispute of the instrument after the demise of the donor. Equally important, the formulation mechanism as one of the elements of the hibah documentation needs to be improved and enhanced in terms of its format, content and verification procedures.

\section{ACKNOWLEDGEMENT}

This article is a part of the findings from the Fundamental Research Grant Scheme which is financially supported by Ministry of Higher Education.

\section{REFERENCES}

Abd. Rahman, M. F. (2007). Bagaimana mengurus harta pusaka. PTS Publications: Kuala Lumpur.

Abdul Rahman, N., et al. (2016). Hibah 'Umra dan Ruqba dalam alUmm: Satu analisis. Jurnal Sultan Alauddin Sulaiman Shah, 3(2), 288-298.

Abdul Rashid, R., \& Ahmad, N. (2013). Pengurusan harta melalui hibah: Kepentingan dan manfaat dari pelbagai aspek untuk kemajuan ummah. Jurnal Hadhari, 5(1), 91-104. 
'Ali Haydar. (t.t.). Durar al-Hukkam Sharh Majallat al-Ahkam, j. 2. Beirut: Dar al-Kutub al-'Ilmiyyah.

Abi al-Tayyib Muhammad Shams. (1979), 'Awn al-Ma'bud Sharh Sunan Abi Dawud, j. 9. Dar al-Fikr

Ahmad Farraj Husayn. (1986). Ahkam al-Wasaya wa al-Awqaffi alShari'ah al-Islamiyyah. Beirut: Dar al-Jami'iyyah.

Ahmad Hidayat. (2002). Bagaimana membuat wasiat, KL: APIUM. Al-'Asqalani, Ahmad bin 'Ali bin Muhammad bin Hajar. (1979).

Talkhis al- Habir, j. 3. Kaherah: Maktabat al-Kuliyyah alAzhariyyah.

Al-Bayhaqi, Abi Bakr Ahmad bin al-Husayn bin 'Ali. (t.t.). al-Sunan al-Kubra, j. 6. Beirut: Dar al-Fikr.

Al-Bukhari, Muhammad bin Isma'il bin Ibrahim. (t.t.). al-Adab alMufrad, j. 4. Jamamizah: Maktabat al-Adab wa Matba'atuha. Al-Kasani, Abi Bakr bin Mas'ud. (2003). Badai 'al-Sanai 'fi Tartib al-Sharai', j. 8. Beirut: Dar al-Kutub al-'Ilmiyyah.

Al-Khatib, Muhammad al-Sharbini. (t. t.). Mughni al-Muhtaj, j. 4. Beirut: Dar Ihya' al-Turath al-'Arabi.

Al-Nawawi, Abi Zakariyya Mahy al-Din. (t. t.). al-Majmu'Sharh alMuhadhdhab, j. 15, Beirut: Dar al-Fikr.

Al-Nawawi, Abi Zakariyya Mahy al-Din. (1985). Rawdat alTalibin, j. 5. Beirut: al-Maktab al-Islami.

Al-Nawawi, Abi Zakariyya Mahy al-Din. (2003). Sahih Muslim bi Sharh al-Nawawi, j. 4. Kaherah: Dar al-Manar.

Al-Ramli, Muhammad bin Abi al- 'Abbas. (1967). Nihayat alMuhtaj Ila Sharh al-Minhaj, j. 5. Kaherah: Mustafa al-Babi al-Halabi wa Awladuh.

Al-Sayyid Sabiq.(t.th). Fiqh al-sunnah. Jil. 3. Kaherah: Maktabah Dar al-Turath.

Al-Wahhab, Abi Muhammad, 'Abd. (1998). al-Ma'unah 'ala Madhhab 'Alim al-Madinah, j. 2. Beirut: Dar al-Kutub al'Ilmiyyah.

Al-Zuhaily, Muhammad. (2001). Al-Faraid Wa al-Mawarith Wa alWasoya, Damsyiq:Dar al-Kalim al-Tayyib.

Awang, M. R. (2003). Pelaksanaan harta hibah. Dlm Isu Syariah dan Undang-undang, Siri 12. Bangi: Jabatan Syariah UKM.

Awang, M. R. (2008). Wasiat kepada ahli waris menurut pandangan fuqaha' dan kedudukannya di negara-negara Islam. Kertas kerja Bengkel Pemantapan Harta Sumber Am: Wasiat. 
Badran Abu al-'Aynayn Badran. (1985). al-Mawarith wa alWasiyyah wa al-Hibbah fi al-Shari'ah al-Islamiyyah wa alQanun. Misr: Muassasah Shabab al-Jami'ah al-Iskandariyyah. Bahuti, Mansur bin Yunus. (1982). Kashshaf al-Qina "an Matan alIqna', j. 4. Beirut: Dar al-Fikr.

Bisyuni 'Ali, Judah 'Abd al-Ghani, \& Nasr Farid Muhammad Wasil. (1997). Ahkam al-Mirath wa al-Wasiyyah fi al-Shari'ah alIslamiyyah. t.tp: t.pt.

Hisham Qublan. (1985). al-Wasiyyah al-Wajibah fi al-Islam. Beirut: Manshurat Bahr al- Mutawassit.

Ibn Rushd, Muhammad bin Ahmad. (2003). Bidayat al-Mujtahid wa Nihayat al-Muqtasid, j. 5. Beirut: Dar al-Kutub al-'Ilmiyyah. Jabatan Kehakiman Syariah Malaysia. (2006). Jurnal Hukum, Jld. XXI(II). Putrajaya.

Jabatan Kehakiman Syariah Malaysia. (2004). Jurnal Hukum, Jld XVIII(I). Putrajaya.

Jabatan Kehakiman Syariah Malaysia. (2001). Jurnal Hukum, Jld $X V I I(\mathrm{I})$. Putrajaya.

Suruhanjaya Sekuriti. (2006). Keputusan Majlis Penasihat Syariah Suruhanjaya Sekuriti. Edisi ke-2. Kuala Lumpur.

Majallah Majma 'al-Fiqh al-Islami. (1990). j. 1, bil. 6.

Muda, M. Z., \& Awang, M. R. (2006). Undang-undang pusaka Islam: Pelaksanaan di Malaysia, Bangi:UKM.

Muda, M. Z., \& Jusoh, M. S. (2004). Konsep wasiat wajibah dalam Islam. Dlm. Mohamad Zaini Yahaya et al., (pnyt.), Isu Syariah dan Undang-undang Siri 13. Bangi: Jabatan Syariah, Fakulti Pengajian Islam, Universiti Kebangsaan Malaysia. Anjuran Jabatan Wakaf, Zakat dan Haji, Jabatan Perdana Menteri. Hotel Quality City Centre, Jalan Raja Laut, Kuala Lumpur, 28 - 30 April.

Muda, M. Z. (2008). Instruments of hibah and wills: Analysis of the regulations and applications in Malaysia. Jurnal Syariah. Jabatan Kehakiman Syariah Malaysia.

Muhammad Abu Zahrah. (1978). Sharhu Qanun al-Wasiyyah, Kaherah: Dar al-Fikr al- 'Arabi.

Muhammad al-Zuhayli. (2001). al-Fara'id wa al-Mawarith wa alWasaya. Beirut: Dar al- Kalam al-Tayyib. 
Muhammad Fathullah Al Haq bin Muhamad Asni et al. (2016). Fatwa concerning Qabd in Hibah and the insertion of Qabd element in States Fatwa in Malaysia, Journal of Islamic Studies and Culture, 4(1), 143-154.

Muhammad Hasan al-Himsi. (1984). Quran Karim: Tafsir Wabayan Ma'a Faharis Kamilah Lil Mawadhi' Wal Alfadz, Beirut: Dar al-Rasyid.

Muhammad Ramiz Abd al-Fattah al-Azizi. (2003). al-Mirath wa alWasiyyah. Jordan: Dar al- Furqan li al-Nashr wa al-Tawzi'.

Mohd Nor, A. H., et al. (2018). Kaedah-kaedah pembuktian kes hibah di mahkamah syariah di Malaysia: Rujukan kes-kes dalam Jurnal Hukum, Malaysian Journal of Syariah and Law, 8 (2).

Mohamed Said, N., et al. (2018). Keperluan saksi dalam permohonan pengesahan kes hibah di mahkamah syariah. Journal of Contemporary Islamic Law, 3(2), 20-27.

Mustofa al-Khin, Mustofa al-Bugho \& Ali al-Syarbaji. (2003). Kitab Fikah Mazhab Syafie. Terj. Jld 5\&6. Kuala Lumpur Pustaka Salam Sdn Bhd.

Nasrul Hisyam et al. (2017). Konsep hibah bersyarat dan aplikasinya dalam perancangan harta. UMRAN - International Journal of Islamic and Civilizational Studies, 3, 3-1 (2017) 32-41.

Noor Lizza binti Mohamed Said et al. (2010). Qabd dan hukum penarikan balik hibah. Jurnal Muamalat, 3 .

Qalyubi, Shihab al-Din Ahmad bin Ahmad bin Salamah \& 'Umayrah, Shihab al-Din Ahmad al-Barlisi (t.t.). Hashiyatan Qalyubi wa 'Umayrah, j. 3, T.P: Dar al-Fikr.

Retrieved from www.wasiyyahshoppe.com.my (25 October 2018).

Retrieved from https://www.amanahraya.my/wp-content/ uploads/2018/09/Amanahraya_Trust_BM_CS6.pdf October 2018).

Retrieved from http://efdpapps.mfa.org.my/franchise-listing/ amanah-hibah-sdn-bhd (15 November 2018).

Wahbah al-Zuhayli. (1989). al-Fiqh al-Islami wa adillatuh. Juz. 5 \& 8. Damsyiq: Dar al-Fikr.

Wan Harun, W. A. H. (2006). Pengurusan dan pembahagian harta pusaka. Dewan Bahasa Dan Pustaka.

Yaakob, O. (2008). Pembentukan trust hibah. KL:UM. 